\title{
PENGARUH PEMBERIAN JUS BIJI PEPAYA (CARICA PAPAYA LINN.) TERHADAP KADAR ASAM URAT TIKUS SPRAGUE DAWLEY DISLIPIDEMIA
}

\author{
Cut Arsyiyanti, Ahmad Syauqy ${ }^{*}$, Kusmiyati Tjahjono*) \\ Program Studi Ilmu Gizi Fakultas Kedokteran Universitas Diponegoro \\ Jl.Dr.Sutomo No.14, Semarang, Telp (024) 8453708, Email : gizifk@undip.ac.id
}

\begin{abstract}
Backgorund: Uric acid is the end product of purin metabolism which if it exists in an excessive level it can induce many serious illness such as gout. Papaya seeds contain phytochemical elements such as flavonoid, saponin, and tannin which can normalize the lipid level profile and lower the uric acid level.. This study aims to get the information on the effect of papaya seeds juice on uric acid level in dislipidemic rats.

Methods: This study is a true experimental with pre-post test randomized control group design towards 24 Sprague Dawley dislipidemic rats which were randomized into 4 groups. There were negative control group that was only given standard diet, positive control group that were given standard and high fat diet, and two treatment groups that were given high fat diet also papaya seeds juice at dosages $400 \mathrm{mg}$ and $800 \mathrm{mg}$ for 30 days. Uric acid level checked with spectrophotometry. Data were analysed by Paired t-test, Annova and also LSD test with $95 \%$ CI.

Results: Alteration of uric acid level in negative control, positive control, and treatment groups that were given papaya seeds juice at dosages $400 \mathrm{mg}$ and $800 \mathrm{mg}$ respectively $-11,21$ ( $p=0,352), 18,91 \quad(p=0,360),-30,43$ $(p=0,024)$, and -16,67( $p=0,127)$. Significancy between all of groups by Anova test was $p=0,017$. Then Post-hoc test between negative control and treatment groups at dosages $400 \mathrm{mg}$ and $800 \mathrm{mg}$ were $p=0,003$ and $p=0,019$ respectively.

Conclusion: The administration of papaya seeds juice for 30 days at dosages $400 \mathrm{mg} / \mathrm{rat} /$ day significantly decrease uric acid level in dislipidemic rats.
\end{abstract}

Keywords: papaya seeds juice; flavonoid; saponin; tannin; uric acid

\begin{abstract}
ABSTRAK
Latar Belakang : Asam urat merupakan produk akhir metabolisme purin yang jika jumlahnya berlebih dapat memicu berbagai macam penyakit diantaranya gout. Biji pepaya mengandung zat fitokimia seperti flavonoid, saponin, dan tanin yang dapat menormalkan kadar profil lipid dan menurunkan kadar asam urat. Penelitian ini bertujuan untuk mengetahui pengaruh jus biji pepaya terhadap kadar asam urat pada tikus dislipidemia.

Metode: Jenis penelitian ini adalah true experimental dengan pre-post test randomized control group design terhadap 24 ekor tikus Sprague Dawley dislipidemia yang kemudian dibagi secara acak dalam 4 kelompok yaitu kelompok kontrol negatif yang hanya diberikan pakan standar, kontrol positif yang diberikan pakan standar dan tinggi lemak, serta dua kelompok perlakuan yang diberikan pakan standar, tinggi lemak dan jus biji pepaya dengan dosis $400 \mathrm{mg}$ dan $800 \mathrm{mg}$ selama 30 hari. Kadar Asam urat diperiksa dengan metode Spektrofotometri. Data di analisis dengan uji Paired t-test dan Anova serta uji LSD pada tingkat kepercayaan 95\%.

Hasil: Perubahan kadar asam urat kelompok kontrol negatif, $k$

ontrol positif dan perlakuan $400 \mathrm{mg}$ dan $800 \mathrm{mg}$ secara berturut-turut adalah-11,21 (p=0,352), 18,91 (p=0,360), 30,43 (p=0,024), dan -16,67( $p=0,127)$. Perubahan kadar asam urat antar kelompok dengan uji Anova menunjukkan signifikansi sebesar 0,017. dilanjutkan uji Post-Hoc antara kelompok kontrol negatif dengan kelompok perlakuan dosis $400 \mathrm{mg}$ dan $800 \mathrm{mg}$ menunjukkan signifikansi berturut-turut 0,003 dan 0,019.

Simpulan: Pemberian jus biji pepaya selama 30 hari pada dosis 400 mg/ekor/hari efektif menurunkan kadar asam urat pada tikus dislipidemia.
\end{abstract}

Kata kunci : Jus biji pepaya; flavonoid; saponin; tanin; asam urat

\section{PENDAHULUAN}

Asam urat merupakan produk akhir metabolisme senyawa purin yang kemudian dikeluarkan melalui urin, feses, dan keringat. ${ }^{1}$ Kelebihan asam urat dalam darah (hiperurisemia) menyebabkan asam urat mengendap di sendi dan menimbulkan peradangan sendi (gout).
Hiperurisemia lebih banyak dijumpai pada pria daripada wanita. ${ }^{2}$ Hal ini dikarenakan wanita mempunyai hormon estrogen yang membantu meningkatkan ekskresi asam urat di ginjal. ${ }^{3}$

Berdasarkan laporan Dinas Kesehatan Provinsi Jawa Tengah, jumlah kasus hiperurisemia dari tahun ke tahun mengalami peningkatan 
dibandingkan dengan kasus penyakit tidak menular lainnya. Hasil survei epidemiologik yang dilakukan di Bandungan, Jawa Tengah terhadap 4.683 sampel didapatkan bahwa prevalensi hiperurisemia sebesar 24,3\% pada laki-laki dan $11,7 \%$ pada wanita. ${ }^{4}$ Tahun 2007 , tercatat proporsi kasus hiperurisemia di Tegal sebesar 5,7\% dan meningkat sebesar $8,7 \%$ pada tahun $2008 .{ }^{5}$ Jika kondisi tersebut dibiarkan tanpa penanganan maka akan menimbulkan risiko penyakit seperti peradangan sendi (gout), hipertensi, diabetes mellitus, dan gagal ginjal. ${ }^{6}$

Faktor yang mempengaruhi peningkatan kadar asam urat dalam darah diantaranya gangguan pada ginjal. Hal ini membuat ginjal tidak mampu mengeluarkan asam urat dengan baik sehingga terjadi pengendapan yang terus-menerus dan menyebabkan terjadinya pengkristalan. ${ }^{7} \quad$ Faktor lainnya yakni tingginya asupan yang mengandung purin, yang kemudian mengalami metabolisme membentuk asam urat. $^{8}$ Bahan makanan yang mengandung purin diantaranya daging, jeroan, kepiting, kerang, keju, dan biji-bijian. ${ }^{9}$ Biji-bijian seperti biji kedelai, biji melinjo dan biji bunga matahari pada penelitian sebelumnya telah terbukti dapat meningkatkan kadar asam urat karena mengandung DNA dan RNA yang berisi nukleotida purin sehingga bahan makanan ini dibatasi untuk penderita asam urat. ${ }^{10-12}$. Namun, biji-bijian seperti biji kopi yang juga mengandung DNA dan RNA pada penelitian sebelumnya menyimpulkan bahwa larutan biji kopi dapat menurunkan kadar asam urat pada tikus percobaan. ${ }^{13}$

Faktor yang dapat menurunkan kadar asam urat diantaranya diit rendah purin dan terapi medik. Selain itu terdapat senyawa-senyawa yang telah terbukti klinis dapat menurunkan kadar asam urat. ${ }^{1}$ Penelitian di Bogor menyebutkan bahwa zat seperti flavonoid dan alkaloid dalam daun sidaguri dapat menurunkan kadar asam urat. ${ }^{14}$ Penelitian lainnya menyebutkan bahwa zat seperti flavonoid, antosianin, tanin, dan saponin yang terkandung di dalam kelopak rosela berpotensi menurunkan asam urat dengan cara menghambat kerja enzim xantin oksidase yang berfungsi mengubah purin menjadi asam urat. ${ }^{15,16}$

Pepaya (Carica papaya L.) merupakan tanaman yang banyak dibudidayakan di Indonesia. Semua bagian tanaman pepaya dapat dimanfaatkan, termasuk biji pepaya. Pemanfaatan biji pepaya saat ini hanya digunakan sebagai bibit dan lebih banyak yang dibuang. ${ }^{17}$ Hasil analisis fitokimia yang dilakukan di Afrika menunjukkan biji pepaya mengandung flavonoid, tanin, saponin, anthraquinon, dan anthosianosid. ${ }^{18,19}$ Flavonoid, tanin, dan saponin dari penelitian sebelumnya telah terbukti dapat menurunkan asam urat. ${ }^{14,15}$

Penelitian tentang pengaruh biji pepaya dalam bidang kesehatan masih sangat terbatas. Penelitian di Afrika membuktikan bahwa ekstrak biji pepaya cair dapat menormalkan kadar profil lipid secara signifikan pada galur tikus Wistar jantan. ${ }^{19}$ Hasil penelitian ini dapat diterapkan dalam terapi diit pasien dislipidemia. Hubungan hiperurisemia dengan dislipidemia pada penelitian di Kuwait menyimpulkan bahwa kondisi hiperurisemia umum terjadi pada pasien dislipidemia. Hal tersebut terjadi karena bahan makanan yang mengandung tinggi kolesterol juga mengandung tinggi purin seperti jeroan, otak, kepiting, dan lainnya. ${ }^{20}$

Biji pepaya merupakan golongan biji-bijian. Beberapa biji-bijian mengandung DNA dan RNA yang dibentuk dari senyawa purin yang dapat meningkatkan asam urat darah. Namun penelitian lain menyebutkan bahwa beberapa senyawa yang ada didalam biji pepaya dapat menurunkan kadar asam urat dalam darah karena mengandung senyawa flavonoid, saponin dan tanin. ${ }^{14,15,21} \mathrm{Hal}$ ini yang mendorong peneliti untuk melihat pengaruh pemberian biji pepaya terhadap penurunan kadar asam urat pada galur tikus Sprague Dawley dislipidemia.

Peneliti mengolah biji pepaya menjadi jus agar zat gizi didalamnya tidak banyak yang hilang. Dosis pemberian jus biji pepaya adalah 400 $\mathrm{mg} /$ ekor/hari dan $800 \mathrm{mg} / \mathrm{ekor} /$ hari selama 30 hari. Penentuan dosis dan lama penelitian didasarkan pada penelitian sebelumnya yang membuktikan dosis efektif jus biji pepaya sebanyak $400 \mathrm{mg} /$ hari selama 30 hari. ${ }^{19}$ Pemilihan dua kali dosis efektif yaitu $800 \mathrm{mg} / \mathrm{ekor} / \mathrm{hari}$ bertujuan untuk menganalisis efek perubahan yang paling signifikan terhadap kadar asam urat.

\section{METODE PENELITIAN}

Penelitian ini berjenis True Experimental dengan pre-post test randomized control group design. ${ }^{22}$ Variabel bebas pada penelitian ini adalah pemberian jus biji pepaya dalam berbagai dosis sedangkan variabel tergantung dalam penelitian ini adalah kadar asam urat. Penelitian dilakukan di Laboratorium Biologi FMIPA Universitas Negeri Semarang.

Subjek penelitian yang digunakan adalah tikus jantan galur Sprague Dawly umur 8 bulan dengan berat badan rata-rata 180-200 gram yang diperoleh 
dari Unit Pengembangan Hewan Percobaan (UPHP) Universitas Gadjah Mada, Yogyakarta. Perhitungan jumlah sampel pada penelitian ini menggunakan rumus federer dan didapatkan besar sampel minimal 6 ekor per kelompok, sehingga total sampel adalah 24 ekor. ${ }^{23}$ Seluruh subjek terlebih dahulu mengalami masa adaptasi yaitu diberi pakan standar sebanyak 20 gram/ekor/hari selama 7 hari.

Selanjutnya dengan simple random sampling, subjek dibagi menjadi 4 kelompok, satu kelompok sebagai kontrol negatif, satu kelompok sebagai kontrol positif dan dua kelompok perlakuan. Kelompok kontrol negatif diberikan pakan standar, kelompok kontrol positif dan kelompok perlakuan diberi pakan standar serta pakan tinggi lemak selama 30 hari. Sebelum memasuki tahap intervensi dilakukan pengambilan darah awal. Pada tahap intervensi, pakan standar dan tinggi lemak tetap dilanjutkan dan ditambahkan jus biji pepaya dengan dosis yang berbeda.

Untuk membuat kondisi dislipidemia pada hewan coba digunakan telur puyuh dikarenakan kadar kolesterol yang terdapat pada telur puyuh lebih tinggi dibanding telur lainnya yaitu sebanyak $3.640 \mathrm{mg} / 100$ gram bahan makanan. ${ }^{24,25}$ Telur puyuh yang diberikan sebelumnya diblender terlebih dahulu. Dosis pemberian telur puyuh sebanyak 2 $\mathrm{ml} / \mathrm{ekor} /$ hari.

Pembuatan jus biji pepaya dilakukan dengan cara menghaluskan biji pepaya menggunakan blender, kemudian ditimbang sebanyak $400 \mathrm{mg}$. Setelah itu tambahkan air hingga $1 \mathrm{ml}$ lalu disaring. Air yang dibutuhkan untuk membuat jus biji pepaya $400 \mathrm{mg} / \mathrm{ml}$ adalah $580 \mathrm{mg}$, sehingga perbandingan biji pepaya dan air ialah $40: 58$. Untuk mendapatkan jus biji pepaya dengan kadar $800 \mathrm{mg}$ dapat mengambil $2 \mathrm{ml}$ dari kadar $400 \mathrm{mg}$ yang telah dibuat. Pemberian jus dan pakan tinggi lemak dilakukan dengan sonde.

Pengambilan darah subjek sebelum intervensi untuk melihat kadar asam urat tiap kelompok perlakuan. Sedangkan kadar asam urat akhir diambil setelah 30 hari masa intervensi dilakukan untuk melihat pengaruh pemberian jus biji pepaya terhadap kadar asam urat. Sampel darah diambil sebanyak $2 \mathrm{ml}$ melalui pleksus retroorbitalis dan dimasukkan ke dalam tabung bersih, kemudian darah di-sentrifuge untuk mendapatkan serumnya. Kadar asam urat ditentukan dengan metode spektrofotometri. $^{23}$

Data yang diperoleh diolah dengan program komputer. Sebelumnya, data diuji normalitasnya dengan menggunakan uji Shapiro-Wilk. Perbedaan kadar asam urat sebelum dan sesudah perlakuan menggunakan uji $\mathrm{t}$ berpasangan. Perbedaan pengaruh dosis dari keempat kelompok perlakuan dianalisis menggunakan uji statistik ANOVA dan uji lanjut LSD (Least Significant Difference). ${ }^{26}$

\section{HASIL PENELITIAN \\ Kandungan zat jus biji pepaya}

Kandungan zat fitokimia dan purin dalam 100 gram biji pepaya dalam bentuk bahan utuh dan jus ditampilkan pada tabel 1 .

Tabel 1. Kandungan zat fitokimia dan purin dalam 100 gram biji pepaya

\begin{tabular}{ccc}
\hline & $\begin{array}{c}\text { Jus biji pepaya } \\
(\mathbf{m g} / \mathbf{1 0 0} \text { g bahan })\end{array}$ & $\begin{array}{c}\text { Biji pepaya } \\
(\mathbf{m g} / \mathbf{1 0 0 g} \text { bahan })\end{array}$ \\
\hline Flavonoid & 646,1 & 947,7 \\
\hline Saponin & 69,3 & 88,39 \\
\hline Tanin & 140,9 & 189,35 \\
\hline Purin & 0 & 0 \\
\hline
\end{tabular}

Analisis fitokimia dan purin pada tabel 1 diperoleh dari Laboratorium kimia Universitas Muhammadiyah Malang, Jawa Timur. Pengujian ini menggunakan dua jenis perlakuan terhadap biji pepaya, yaitu dalam bentuk biji pepaya utuh dan dalam bentuk jus. Dari hasil diatas menunjukkan bahwa kadar fitokimia antara biji pepaya utuh dengan jus biji pepaya mengalami perbedaan, hal ini dikarenakan adanya penambahan air serta proses penyaringan pada jus. Kadar purin yang didapat dari biji pepaya utuh dan jus adalah sebesar $0 \mathrm{mg}$ per 100 gram biji pepaya.

Kadar Asam Urat sebelum dan sesudah pemberian jus biji pepaya

Subjek pada penelitian ini dibagi menjadi 4 kelompok yaitu kelompok kontrol negatif (P0) yang selama penelitian hanya diberikan pakan standar, kelompok kontrol positif (P1) yang selama penelitian diberikan pakan standar dan tinggi lemak, kelompok perlakuan pertama (P2) yang diberikan pakan standar dan tinggi lemak sebelum 
intervensi dan ditambah dengan pemberian jus biji pepaya dengan dosis $400 \mathrm{mg}$ saat intervensi, serta kelompok perlakuan kedua (P3) yang diberikan pakan standar dan pakan tinggi lemak sebelum intervensi dan ditambah pemberian jus biji pepaya dengan dosis $800 \mathrm{mg}$ saat intervensi.

Sebelum intervensi, 24 ekor tikus mengalami masa aklimatisasi atau masa adaptasi dan keadaan dislipidemia. Setelah dilakukan pengambilan darah awal, intervensi dilakukan yaitu pemberian jus biji pepaya dengan dosis yang berbeda selama 30 hari. Tabel 2 menampilkan pengaruh rata-rata kadar asam urat sebelum dan sesudah pemberian intervensi dan perbedaannya antar kelompok perlakuan, serta pada tabel 3 dan 4 menampilkan uji lanjutan dengan menggunakan LSD.

Tabel.2 Rata-rata kadar asam urat sebelum dan sesudah pemberian jus biji pepaya selama 30 hari

\begin{tabular}{ccccccc}
\hline $\begin{array}{c}\text { Kadar } \\
\text { Asam Urat }\end{array}$ & $\mathrm{n}$ & $\begin{array}{c}\text { Sebelum } \\
(\mathrm{mg} / \mathrm{dl})\end{array}$ & $\begin{array}{c}\text { Sesudah } \\
(\mathrm{mg} / \mathrm{dl})\end{array}$ & $\begin{array}{c}\Delta \\
(\mathrm{mg} / \mathrm{dl})\end{array}$ & $\begin{array}{c}\Delta \\
\%\end{array}$ & $\mathrm{p}$ \\
\hline $\mathrm{PO}$ & 6 & $1,07 \pm 0,13^{\mathrm{a}}$ & $0,95 \pm 0.39^{\mathrm{a}^{*}}$ & $-0,12^{\mathrm{a}^{*}}$ & -11.21 & $0,352^{\mathrm{b}}$ \\
\hline $\mathrm{P} 1$ & 6 & $1.11 \pm 0.26^{\mathrm{a}}$ & $1,32 \pm 0.26^{\mathrm{a}^{*}}$ & $0,21^{\mathrm{a}^{*}}$ & 18.91 & $0,360^{\mathrm{b}}$ \\
\hline $\mathrm{P} 2$ & 6 & $1,15 \pm 0.27^{\mathrm{a}}$ & $0,80 \pm 0.11^{\mathrm{a}^{*}}$ & $-0,35^{\mathrm{a}^{*}}$ & $-30,43$ & $0.024^{\mathrm{b}^{*}}$ \\
\hline $\mathrm{P} 3$ & 6 & $1,20 \pm 0.17^{\mathrm{a}}$ & $1.00 \pm 0.35^{\mathrm{a}^{*}}$ & $-0,20^{\mathrm{a}^{*}}$ & $-16,67$ & $0.127^{\mathrm{b}}$ \\
\hline
\end{tabular}

${ }^{a}$ Uji Anova, ${ }^{b}$ Uji Paired t-test, *berbeda bermakna

Tabel 3. Hasil analisis lanjut asam urat sesudah intervensi

\begin{tabular}{ccc}
\hline Uji Lanjut & Perbedaan rerata & p \\
\hline P0 vs P1 & 0.37 & $0.045^{*}$ \\
\hline P0 vs P2 & 0.15 & 0.392 \\
\hline P0 vs P3 & 0.05 & 0.774 \\
\hline P1 vs P2 & 0.52 & $0.007^{*}$ \\
\hline P1 vs P3 & 0.32 & 0.08 \\
\hline P2 vs P3 & 0.2 & 0.252 \\
\hline
\end{tabular}

*berbeda bermakna

Tabel 4. Hasil analisis lanjut delta asam urat antara kelompok

\begin{tabular}{ccc}
\hline Uji Lanjut & Perbedaan rerata & p \\
\hline P0 vs P1 & 0.35 & 0.052 \\
\hline P0 vs P2 & 0.23 & 0.183 \\
\hline P0 vs P3 & 0.08 & 0.628 \\
\hline P1 vs P2 & 0.58 & $0.003^{*}$ \\
\hline P1 vs P3 & 0.43 & $0.019^{*}$ \\
\hline P2 vs P3 & 0.15 & 0.386 \\
\hline
\end{tabular}

*berbeda bermakna

Hasil uji pada tabel 2 menunjukkan terdapat perbedaan kadar asam urat yang bermakna sebelum dan sesudah intervensi pada kelompok P2 ( $\mathrm{p}=0,024)$. Pemberian jus biji pepaya pada dosis $400 \mathrm{mg}$ ternyata lebih efektif menurunkan kadar asam urat dibandingkan dosis $800 \mathrm{mg}$. Pada dosis $800 \mathrm{mg}$ tetap memberikan efek penurunan yaitu sebesar $16,67 \%$ walaupun secara statistik tidak bermakna $(\mathrm{p}=0,127)$.
Hasil uji anova asam urat sebelum intervensi, diperoleh nilai signifikansi pada variabel tersebut sebesar 0,696 yang menunjukkan tidak adanya perbedaan secara bermakna antar kelompok perlakuan sebelum intervensi. Pada kelompok asam urat sesudah intervensi, diperoleh nilai signifikansi sebesar 0,045 yang menunjukkan adanya perbedaan bermakna antar kelompok perlakuan sesudah dilakukannya intervensi. Uji lanjutan antar kelompok sesudah intervensi yang 
ditampilkan pada tabel 3 menunjukkan bahwa nilai signifikansi antara kelompok P0 dengan P1 adalah sebesar 0,045 $(\mathrm{p}<0,05)$ dan kelompok P1 dengan P2 adalah sebesar 0,007 $(\mathrm{p}<0,05)$. Hal ini menunjukkan terdapat perbedaan yang bermakna antara kelompok kontrol positif dengan kelompok kontrol negatif dan perlakuan $400 \mathrm{mg}$.

Hasil uji anova delta asam urat antar kelompok perlakuan terlihat bahwa kelompok P0, P2, dan P3 mengalami penurunan kadar asam urat sesudah dilakukan intervensi, sedangkan pada kelompok P1 menunjukkan peningkatan kadar asam urat. Hasil uji anova tersebut dilakukan untuk melihat perbedaan delta kadar asam urat antar kelompok, diperoleh nilai signifikansi sebesar
0,017 ( $\mathrm{p}<0,05)$. Hal ini menunjukkan bahwa delta kadar asam urat memiliki perbedaan bermakna. Untuk melihat kelompok mana yang memiliki perbedaan bermakna dilakukan uji lanjut dengan menggunakan LSD (Least Significant Difference) pada tabel 4 yang menyatakan nilai signifikansi antara kelompok P1 dengan P2 dan P3 secara berurutan adalah 0,003 dan $0,019(\mathrm{p}<0,05)$. Hal ini menunjukkan bahwa terdapat perbedaan yang bermakna antara kelompok kontrol positif dengan kelompok perlakuan 400 dan $800 \mathrm{mg}$.

Hal-hal yang dapat mempengaruhi kadar asam urat diantaranya asupan pakan dan berat badan. Diagram asupan pakan subjek selama intervensi ditampilkan pada gambar 1 .

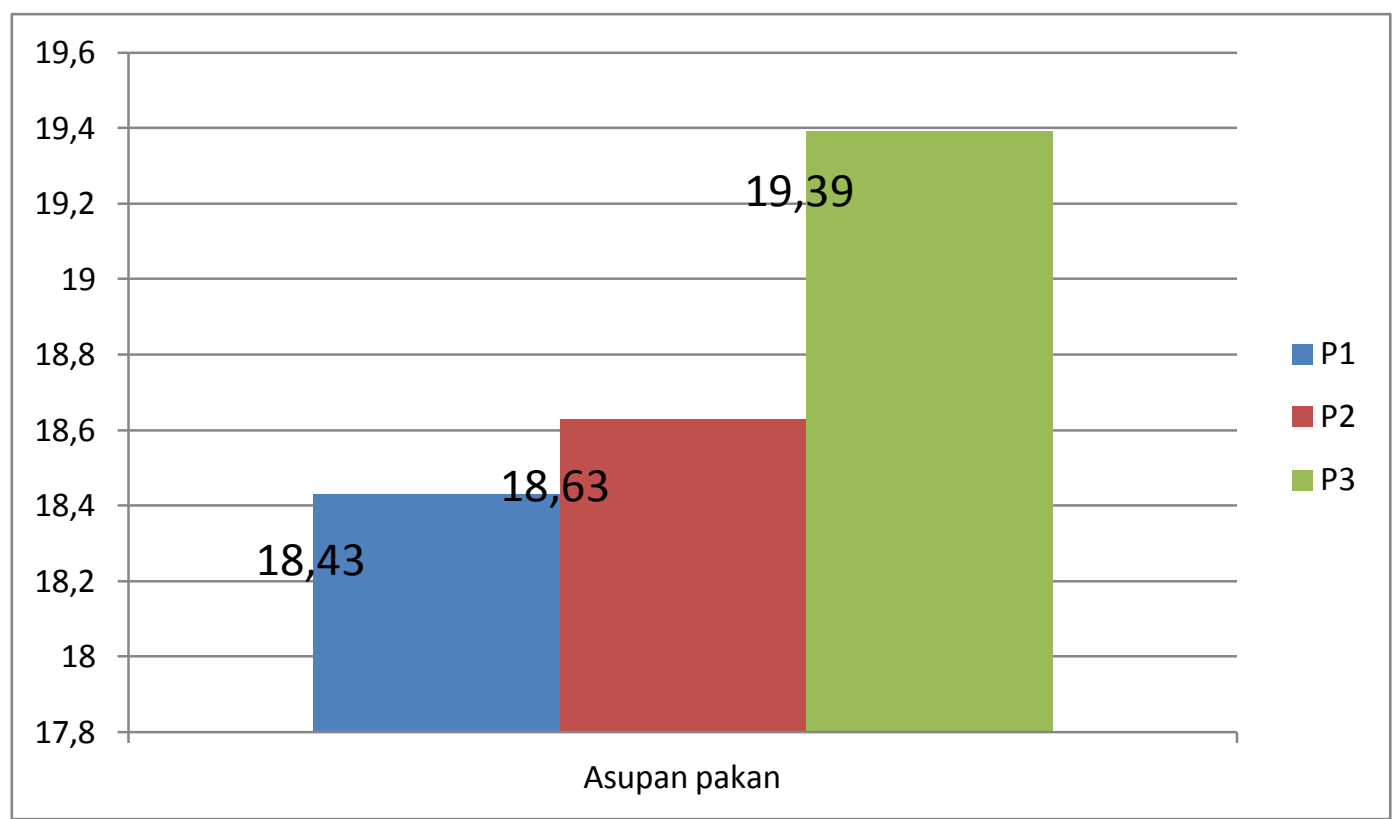

Gambar 1. Diagram asupan pakan selama intervensi pada masing-masing kelompok

Dilihat dari gambar 1 diatas bahwa ratarata asupan pakan yang paling tinggi adalah pada kelompok P3 yaitu sebesar 19,39 gram, sedangkan yang paling rendah adalah pada kelompok $\mathrm{P} 1$ yaitu sebesar 18,43 gram. Perbedaan berat badan awal dan akhir penelitian untuk melihat keterkaitan antara perubahan berat badan dengan kadar asam urat subjek ditampilkan pada tabel 5

Tabel 5. Rata-rata berat badan awal dan akhir penelitian

\begin{tabular}{ccccccc}
\hline $\begin{array}{c}\text { Berat } \\
\text { Badan }\end{array}$ & $\mathrm{n}$ & $\begin{array}{c}\text { Sebelum } \\
\text { (gram) }\end{array}$ & $\begin{array}{c}\text { Sesudah } \\
\text { (gram) }\end{array}$ & $\begin{array}{c}\Delta \\
(\text { gram })\end{array}$ & $\begin{array}{c}\Delta \\
\%\end{array}$ & $\mathrm{p}$ \\
\hline P1 & 6 & $191.5 \pm 127.2$ & $297.7 \pm 11.44$ & $106.2^{\mathrm{a}}$ & 55.46 & $0.000^{\mathrm{b}^{*}}$ \\
\hline P2 & 6 & $204.78 \pm 25.49$ & $313.68 \pm 22.53$ & $108.9^{\mathrm{a}}$ & 53.18 & $\begin{array}{c}0.000 \\
\mathrm{~b}^{*}\end{array}$ \\
\hline P3 & 6 & $198.017 \pm 8.32$ & $311.32 \pm 12.37$ & $113.3^{\mathrm{a}}$ & 87.51 & $0.000^{\mathrm{b}^{*}}$ \\
\hline
\end{tabular}

${ }^{\mathrm{a} U j i}$ Anova ${ }^{\mathrm{b}} \mathrm{Uji}$ Paired $t$-test *berbeda bermakna 
Hasil uji Paired T-test pada tabel 5 diatas dilakukan untuk melihat pengaruh intervensi terhadap berat badan sebelum dan sesudah, diperoleh nilai signifikansi untuk semua kelompok adalah sebesar 0,000 $(\mathrm{p}<0,05)$. Hal ini menunjukkan terdapat perbedaan berat badan secara signifikan pada awal dan akhir penelitian.

Hasil uji Anova dilakukan untuk melihat delta berat badan antar kelompok perlakuan didapat ratarata delta berat badan yang terendah sebesar 106,2 gram yaitu pada kelompok P1 dan delta berat badan tertinggi yaitu sebesar 113.3 gram pada kelompok P3 dan diperoleh nilai signifikansi sebesar 0,676 ( $>00,05)$. Hal ini menunjukkan bahwa delta berat badan tidak memiliki perbedaan yang signifikan.

\section{PEMBAHASAN}

Penelitian ini bertujuan untuk melihat pengaruh lain yang dihasilkan dari pemberian jus biji pepaya terhadap perubahan kadar asam urat tikus dengan dislipidemia. Pada penelitian sebelumnya, jus biji pepaya telah terbukti secara signifikan dapat memperbaiki kadar profil lipid.

\section{Kandungan zat jus biji pepaya}

Pengujian zat fitokimia dan purin pada biji pepaya menggunakan dua jenis perlakuan yaitu dalam bentuk biji pepaya utuh dan dalam bentuk jus. Dari hasil yang ditampilkan pada tabel 2 memperlihatkan adanya perbedaan kadar fitokimia antar keduanya. Kandungan flavonoid dalam biji pepaya utuh adalah sebanyak $947,7 \mathrm{mg}$ sedangkan pada jus biji pepaya $646,1 \mathrm{mg}$, kandungan saponin dalam biji pepaya utuh $88,39 \mathrm{mg}$ sedangkan pada jus 69,3 mg, dan kandungan tanin dalam biji pepaya utuh sebanyak $189,35 \mathrm{mg}$ sedangkan pada jus biji pepaya $140,9 \mathrm{mg}$. Dari hasil tersebut terlihat bahwa biji pepaya utuh mengandung jumlah senyawa yang lebih tinggi dibanding biji pepaya dalam bentuk jus. Hal ini dikarenakan adanya proses penyaringan pada kelompok jus sehingga jumlah senyawa yang dihasilkan lebih rendah. Kandungan senyawa fitokimia ini sesuai dengan analisis fitokimia secara kualitatif pada penelitian sebelumnya yang dilakukan di Afrika yang menunjukkan bahwa biji pepaya mengandung flavonoid, saponin dan tanin. ${ }^{19}$

Kadar purin dalam biji pepaya menunjukkan bahwa pada biji pepaya utuh dan biji pepaya dalam jus memiliki kadar purin $0 \mathrm{mg}$. Beberapa penelitian mengenai biji-bijian seperti biji kedelai, biji melinjo, dan biji bunga matahari memang dapat meningkatkan kadar asam urat karena mengandung purin, namun berbeda dengan penelitian lainnya yaitu pada biji kopi yang membuktikan bahwa secara signifikan biji kopi dapat menurunkan kadar asam urat disamping adanya kandungan purin pada biji kopi tersebut. ${ }^{10-13}$

\section{Kadar Asam Urat sebelum dan sesudah intervensi}

Pemberian jus biji pepaya terbukti dapat menurunkan kadar asam urat. Hal ini terlihat pada tabel 2 yang menampilkan kadar asam urat sebelum dan sesudah pemberian jus biji pepaya. Rata-rata kadar asam urat pada kelompok perlakuan $400 \mathrm{mg}(\mathrm{P} 2)$ dan perlakuan $800 \mathrm{mg}(\mathrm{P} 3)$ mengalami penurunan secara berturut-turut dari $1,15 \mathrm{mg} / \mathrm{dl}$ menjadi $0,8 \mathrm{mg} / \mathrm{dl}$ atau turun sebesar $30,43 \%(\mathrm{p}=0,024)$ dan dari $1,2 \mathrm{mg} / \mathrm{dl}$ menjadi 1,00 $\mathrm{mg} / \mathrm{dl}$ atau turun sebesar $16,67 \% \quad(\mathrm{p}=0,127)$. Penurunan tersebut disebabkan kandungan fitokimia berupa flavonoid, tanin, dan saponin yang terdapat dalam biji pepaya. Dalam 100 gram jus biji pepaya mengandung $646,1 \mathrm{mg}$ flavonoid, 140,9 mg tanin, dan 69,3 mg saponin.

Flavonoid diketahui dapat menurunkan asam urat dengan cara menghambat kerja xantin oksidase. Seperti penelitian sebelumnya yang menunjukkan peran flavonoid yang terdapat dalam herbal sidaguri mempunyai efek penghambat aktivitas xantin oksidase dengan daya inhibisi terkuat. ${ }^{14}$ Flavonoid juga bersifat antioksidan yang dapat menghambat kerja enzim xantin oksidase dan reaksi superoksida, sehingga pembentukan asam urat terhambat. ${ }^{27}$ Tanin dalam bji pepaya dapat menurunkan kadar asam urat dengan cara mengikat radikal selama perubahan purin menjadi asam urat. ${ }^{28}$ Sedangkan saponin dalam biji pepaya bekerja dengan cara mengurangi aktifitas enzim xantin oksidase dalam serum dan meningkatkan tingkat konsentrasi asam urat dalam urin. Hasil penelitian eksperimental pada tikus hiperurisemia yang diberikan senyawa saponin dengan dosis 240 , 120, dan $60 \mathrm{mg}$ dapat menurunkan kadar asam urat secara signifikan. ${ }^{29}$

Hal yang membedakan penelitian ini dengan penelitian sebelumnya adalah pada penelitian ini diit hewan sengaja dikondisikan tidak terkontrol yaitu dengan tetap diberikannya pakan tinggi lemak sehingga untuk membandingkan perubahan kadar asam urat kelompok perlakuan adalah dengan menggunakan kelompok lain yang sama-sama diberikan pakan tinggi lemak namun tidak mendapatkan intervensi. Dari hasil analisis statistik, terlihat bahwa jika dibandingkan dengan kadar asam urat sebelum intervensi, maka dosis $400 \mathrm{mg}$ lebih efektif dan bermakna untuk menurunkan kadar asam urat dibanding dosis 800 
mg, namun jika dibandingkan dengan kelompok kontrol positif maka kedua kelompok perlakuan $400 \mathrm{mg}$ dan $800 \mathrm{mg}$ mempunyai perbedaan yang bermakna.

Hal yang mempengaruhi kadar asam urat adalah perbedaan rata-rata berat badan antar kelompok perlakuan. Pada tabel 5 terlihat bahwa kelompok perlakuan $800 \mathrm{mg}$ mengalami perubahan berat badan yang paling besar yaitu $87,51 \%$. Perubahan ini terjadi akibat tingginya asupan lemak. Hasil samping dari metabolisme lemak yang dikenal dengan benda keton akan meningkat (ketosis) pada subjek yang mendapatkan diit tinggi lemak. Benda keton memiliki sifat asam sehingga dapat menggeser $\mathrm{pH}$ darah menjadi asam. Kondisi asidosis seperti ini dikarenakan bendabenda keton yang lebih tinggi dibanding kecepatan pembuangannya di ginjal. Ginjal yang berfungsi mengeluarkan zat-zat yang tidak diperlukan akan bekerja lebih berat untuk mengeluarkan benda keton sehingga proses pengeluaran zat-zat lain seperti asam urat akan terhambat pengeluarannya sehingga mengakibatkan kadar asam urat dalam darah meningkat ${ }^{21,30}$

Pemberian pakan tinggi lemak pada penelitian ini adalah menggunakan telur puyuh karena bahan makanan ini mengandung jumlah kolesterol yang paling tinggi dibanding bahan makanan lainnya. Kolesterol yang terkandung dalam 100 gram telur puyuh ialah sebesar 3.640 $\mathrm{mg} / \mathrm{dl}^{24,25}$ Peningkatan berat badan ini sesuai dengan hasil penelitian sebelumnya bahwa pemberian telur puyuh sebanyak $2 \mathrm{ml}$ selama 28 hari dapat meningkatkan berat badan subjek sebesar $80,7 \% .^{31}$

Perubahan berat badan juga dipengaruhi oleh asupan pakan standar karena merupakan salah satu sumber energi bagi subjek. Pada gambar 1 terlihat bahwa asupan pakan standar kelompok perlakuan $800 \mathrm{mg}$ merupakan jumlah asupan yang paling tinggi dibanding kelompok lain yaitu sebesar 19,39 gram. Hal inilah yang menyebabkan kadar asam urat meningkat pada kelompok perlakuan $800 \mathrm{mg}$ sehingga penurunan yang dihasilkan lebih kecil dari kelompok perlakuan 400 mg.

\section{KETERBATASAN PENELITIAN}

Keterbatasan dalam penelitian ini adalah subjek tidak dikondisikan hiperurisemia sebelumnya sehingga tidak dapat melihat perubahan yang besar pada subjek perlakuan.

\section{SIMPULAN}

Pemberian jus biji pepaya selama 30 hari pada dosis $400 \mathrm{mg} / \mathrm{ekor} / \mathrm{hari}$ dan $800 \mathrm{mg} /$ ekor/hari dapat menurunkan kadar asam urat masing-masing sebesar $30,43 \%$ dan $16,7 \%$ pada tikus dislipidemia.

\section{SARAN}

Diperlukan penelitian lebih lanjut menggunakan subjek hewan coba mengenai efek jangka panjang dan toksisitas pemberian jus biji pepaya, serta mengenai efek pemberian jus biji pepaya dengan menggunakan subjek manusia.

\section{DAFTAR PUSTAKA}

1. Sustrani L, Alam S, Hadibroto I. Asam Urat: Informasi Lengkap untuk Penderita dan Keluarganya. Jakarta. Gramedia Pustaka Utama; 2004.

2. Prince SA, Wilson LM. Patofisiologi : Konsep Klinis Proses-proses Penyakit Ed.6. Jakarta : EGC; 2005.

3. Asam Urat atau Gout. Nucleus Precise News Letter edisi-1; 2011.

4. Dinas Kesehatan Propinsi Jawa Tengah, Survailens Penyakit Tidak Menular pada Puskesmas dan Rumah Sakit di Jawa Tengah, Semarang; 2007.

5. Rumah Sakit Umum Kardinah, Profil Kesehatan Rumah Sa kit, Tegal; 2008.

6. Luk AJ, Simkin PA. Epidemiologi of Hiperuricemia and Gout. The American Journal of Managed Care, Vol. 11; 2005: 11: 425-442.

7. National Institute of Arthritis and Musculoskeletal and Skin Diseases (Maryland). What is Gout? Maryland: Departement of Health and Human Services Public Health Service, 2010.

8. Choi HK, Mount DB, Reginato AM. Pathognesis of Gout. Annals of Internal Medicine, Vol 143(7), 2005.

9. Mahan LK, Stump ES. Krause's Food, Nutrition, and Diet Theraphy $12^{\text {th }}$ edition. Pensylvania : Saunders; 2007.

10. Matthew JK, Karin MO, Carla S, Peter EH. Infuence of Purine Intake on Uric Acid Excretion in Infants Fed Soy Infant Formulas. Journal of The American College of Nutrition, Vol.19, No. 1, 1622, 2000.

11. Brenes A, Centeno C, Viveros A, Arija I. Effect of Enzyme Addition on the Nutritive Value of High Oleic Acid Sunflower Seeds in Chicken Diets. Poultry Science Association Inc, 87: 2300-2310, 2008.

12. Khushk I, Dahot MU, Balach, Bhutto MA. The Evaluation of Soybean Extracts ini AlloxanInduced Diabetic Rabbit. World Applied Sciences Journal 8 (Special Issue of Biotechnology and Genetic Engineering): ISSN 1818-4952, 2010. 
13. Lelyana R. Pengaruh Kopi Terhadap Kadar Asam Urat Darah (Tesis). Semarang : Universitas Diponegoro. ; 2008.

14. Iswantini $\mathrm{D}$, Rahminiwati $\mathrm{M}$, Januwati $\mathrm{M}$. Bioprospeksi Sidaguri (sida rhombifolia 1.) dan Seledri (apium graveolens 1.) : formulasi obat gout dan aktifitas inhibisinya terhadap xanti oksidase (Skripsi). Bogor : Institus Pertanian Bogor. ; 2004.

15. Yulianto D. Inhibisi Xantin Oksidase Secara In Vitro oleh Ekstrak Rosela (Hibiscus sabdariffa) dan Cuplikan (Physalis angulata)(skripsi). Bogor : Institusi Pertanian Bogor. ; 2009.

16. Silbernagl S. Teks dan Atlas Berwarna Patofisiologi. Jakarta : EGC; 2006.

17. Warisno. Budidaya Pepaya. Yogyakarta: Kanisius; 2003.

18. United Nations Environment Programme(India). Unapproved GM Papaya Found in Japan. Hydersabad: Convention on Biological Diversity, 2012.

19. Adeneye AA, Olagunju JA. Preliminary hypoglycemic and hypolipidemic activities of the aqueous seed extract of Carica papaya Linn. in Wistar rats. Biology and Medicine, Vol. 1 (1): 1-10, 2009.

20. Al-Meshaweh AF, Jafar Y, Asem M, Akanji AO. Determinants of Blood Uric Acid Levels in a Dyslipidemic Arab Population.Medical Principles and Practice, 21 : 209-216, 2012.

21. Murray RK, Granner DK, Rodwell VW. Biokimia Harper edisi 27. (alih bahasa: dr. Brahm U. Pendit). Jakarta: Penerbit Buku Kedokteran EGC; 2006.

22. Supranto J. Teknik Sampling untuk Survey dan Eksperimen. Jakarta : Penerbit PT Rineka Cipta; 2000.

23. Hamdani SPG, Haman H, Susetyowati. High Consumption of Carbohydrate, Protein, Fat as Risk Factor of Dislipidemia in Lectures of Gadjah Mada University (GMU) Having Medical Check Up at GMC Health Center Yogyakarta. Program Faculty of Medicine Gadjah Mada University Yogyakarta. 2011.

24. Dwiloka B. Efek Kolesterlemik Berbagai Telur.Media Gizi dan Keluarga, Desember 2003, 27 (2): 58-65.

25. General Hospital Laboratories

26. Dahlan MS. Statistik untuk Kedokteran dan Kesehatan. Jakarta : Salemba Medical; 2008.

27. Kosman R, Herman H. Uji Efek Penghambatan Enzim Xantin Oksidase oleh Infus Daun Jambu Mede (Anacardium occidentale) Berdasarkan Parameter Farmakokinetik Kofein. Majalah Farmasi dan Farmakologi Vol. 13, No. 1, Maret 2009 (ISSN : 1410-7031)

28. Hatano T, Yasuhara T, Yoshihara R, Agata I. Effect og Interaction of Tannins with Co-existing Substance. Inhibitory Effect of Tannis and Related Polyphenol on Xantine Oxidase. 38 (5) : 1224-9, 1990.
29. Chen GL, Wei W, Xu SY. Effect and Mechanism of Total Saponin of Discorea on Animal Experimental Hyperuricemia. Am J Chin Med, 34 (1) : 77-85, 2006.

30. Emmerson BT. The Management of Gout. New Engl j med. 2007 April; 166:742-748

31. Rully M, Probosari E. Pengaruh pemberian Buah Pepaya (Carica Papaya Linn.) terhadap Kadar Trigliserida pada Tikus Sprague Dawley dengan Hiperkolesterolemia (skripsi). Semarang: Universitas Diponegoro.; 2012. 